\title{
Population genetic structure of the rare species Eryngium maritimum L. (Apiaceae) in the Gulf of Gdańsk: implications for conservation and management
}

\author{
Julita Minasiewicz*, Sulisława Borzyszkowska, Katarzyna Żółkoś, \\ Joanna Bloch-Orłowska \& Renata Afranowicz
}

Department of Plant Taxonomy and Nature Conservation, University of Gdańsk, Al. Legionów 9, 80-441 Gdańsk, Poland, *e-mail: biojm@univ.gda.pl

\begin{abstract}
We examined the genetic structure and diversity of eight populations of Eryngium maritimum L. (Sea Holly) along $150 \mathrm{~km}$ coastline of the Gulf of Gdańsk in Poland. Allozyme electrophoresis revealed two polymorphic loci among the 31 we tested. The populations showed low levels of genetic diversity $(P=6.25, A=1.062, \mathrm{Ht}=0.026)$, with little genetic differentiation between populations $\left(\mathrm{F}_{\mathrm{ST}}=0.03\right)$, although it was statistically significant $(p<0.001)$. The main directions of currents and wind indicate no significant limitations to the transport of seeds between populations in the region. Therefore, the grouping of populations that are mostly congruent with their geographic locations (except HP1) might result from the low efficacy of gene flow by seeds. The significant genetic differentiation of HP1, even from close neighboring populations, might have arisen from the founder effect and barriers to the gene flow caused by anthropogenic factors such as forestation and the construction of breakwaters.
\end{abstract}

Key words: Eryngium maritimum, allozymes, genetic structure, conservation

\section{Introduction}

Coastal dunes and beaches are fragile habitats shaped by natural and anthropogenic factors. Intensive economic development and urbanization affect their stability and persistence. Human impacts on the beaches and dunes in the western part of the Gulf of Gdansk have led to fragmentation and loss of many habitats (Gerstmannowa 1995; Gerstmannowa \& Lenartowicz 1995; Piotrowska 2002). Increasing tourism and recent activities such as riding all-terrain vehicles and kite surfing, have also significantly affected the coastal zone (Żółkoś, unpubl.).

Eryngium maritimum L. (Sea Holly) belongs to a particularly vulnerable group of plants in coastal dune communities. In Poland, Sea Holly has been one of the few species protected since the early twentieth century and is now subject to strict legal protection (Regulation 2004). It is rated a nearly threatened taxon (NT) in the Gdańsk region of Pomerania (Markowski \& Buliński
2004). Historical data on the distribution and abundance of Sea Holly along the stretch of coast we studied show that in the past this species was a common component of sand-dune plant communities (Preuss 1911; Herweg 1914; Chrzanowski 1920; Urbański 1933) but the number and the size of its populations have been reduced because of the increasing fragmentation of its habitat (Kulesza 1928; Lubliner-Mianowska 1958; Ćwikliński 1978; Żółkoś et al. 2007). Habitat fragmentation causes a decrease in genetic connectivity among plant populations, which typically leads to greater inbreeding and a loss of genetic diversity within the fragments over time (Young et al. 1996; Fischer et al. 2000; Aguilar et al. 2006). It is essential to assess the genetic variation of populations, their genetic structure and the forces that shape it to plan proper recovery strategies (Frankham 2005).

Eryngium maritimum is a perennial species of sandy shores in Europe, North Africa and Asia Minor (Hultén \& Fries 1986). It prefers sandy white dunes, although 
in the Baltic coastal zone it frequently grows on stabilized dunes and beaches. Sea Holly is a clonal plant with rhizomes that might be more than four metres. The rhizomes are fragile and deep-reaching, which facilitates vegetative reproduction. The above-ground stems have xeromorphic, wax-covered, spiny leaves and are usually highly branched with many globular flower heads (Stasiak 1988). The young shoots occur 2-3 m from the maternal plant and are often still linked to it deep under the surface of the dunes (Ćwikliński 1972).

Sea Holly is pollinated by insects (Kulesza 1924; Bulak \& Woch 2007), and usually flowers and fruits in its fourth to fifth year of growth (Aviziene et al. 2008). Although Eryngium maritimum flowers abundantly on Polish shores, it seldom reproduces sexually and few of the fruits contain well-developed, potentially fertile seeds (Stasiak 1988; Borzyszkowska unpubl.). Seedlings are quite rare under natural conditions and most perish in summer (Stasiak 1988). Dried stems break off easily at the base in the dispersal period and the plant is rolled by wind along the beach, spreading seeds as it moves. Some plants reach the sea and are further dispersed by water. Sea currents might play an important role in the dispersal of Sea Holly. Westberg and Kadereit (2008) showed how currents influence geographical patterns of genetic variation in this species.

The genetic diversity of Sea Holly populations in Poland has not yet been studied, although low levels of molecular variation have been shown in Norway (Curle et al. 2007) and Mediterranean Basin (Westberg \& Kadereit 2008). Clonal reproduction and the low survival of Sea Holly seedlings in northern localities (Stasiak 1988; see Curle et al. 2007) might reduce effective population size. Habitat fragmentation might compound the decline in genetic variation.

This study aimed to assess the level and patterns of genetic diversity in E. maritimum populations using allozyme electrophoresis, and to determine the species spatial genetic structure and the factors influencing it. Results of genetic research, together with data on current and historical distribution of Sea Holly and habitat availability, allowed us to work out the best strategy for the species conservation.

\section{Material and methods}

\subsection{Study sites and sampling procedures}

Populations of Eryngium maritimum for genetic research were chosen after field work in the summer of 2006 along a $150 \mathrm{~km}$ section of the Gulf of Gdańsk from Władysławowo through the Hel Peninsula to Świbno at Sobieszewo Island (Fig. 1). The entire western shore, including areas managed by the Polish Navy, ports authority and the Chancellery of the President of Poland, were investigated. All coastal habitats, not only those usually occupied by the species, were examined. Numbers of Sea Holly shoots and their distribution were estimated during field studies (Żółkoś et al. 2007). Eight localities spread along the study area were chosen for this investigation (Fig. 1, Table 1). Four of the sites were on the Hel Peninsula, three on the seaboard (HP2, HP3, HP4) and one on the gulf (HP1). The other sites: Rewa-Mechelinki (RME), Babie Doły (BDO), Stogi-Górki Zachodnie (SGZ) and Sobieszewo Island (SOI), were in the south-western and southern Gulf of Gdańsk.

Samples for allozyme studies were collected in 2006. The youngest leaves were collected from 286 flowering plants at least two meters apart to avoid resampling the same clone (Table 1). Fresh leaf material was stored at $-70^{\circ} \mathrm{C}$ before analysis.

\subsection{Enzyme electrophoresis}

About one $\mathrm{cm}^{2}$ of the uppermost leaves was homogenized in the extraction buffer (Soltis et al. 1983). 15 enzyme systems were analyzed using three buffer systems with $11 \%$ starch gel. Shikimate dehydrogenase (SKD, EC. 1.1.1.25), glyceraldehyde-3-phosphate de-

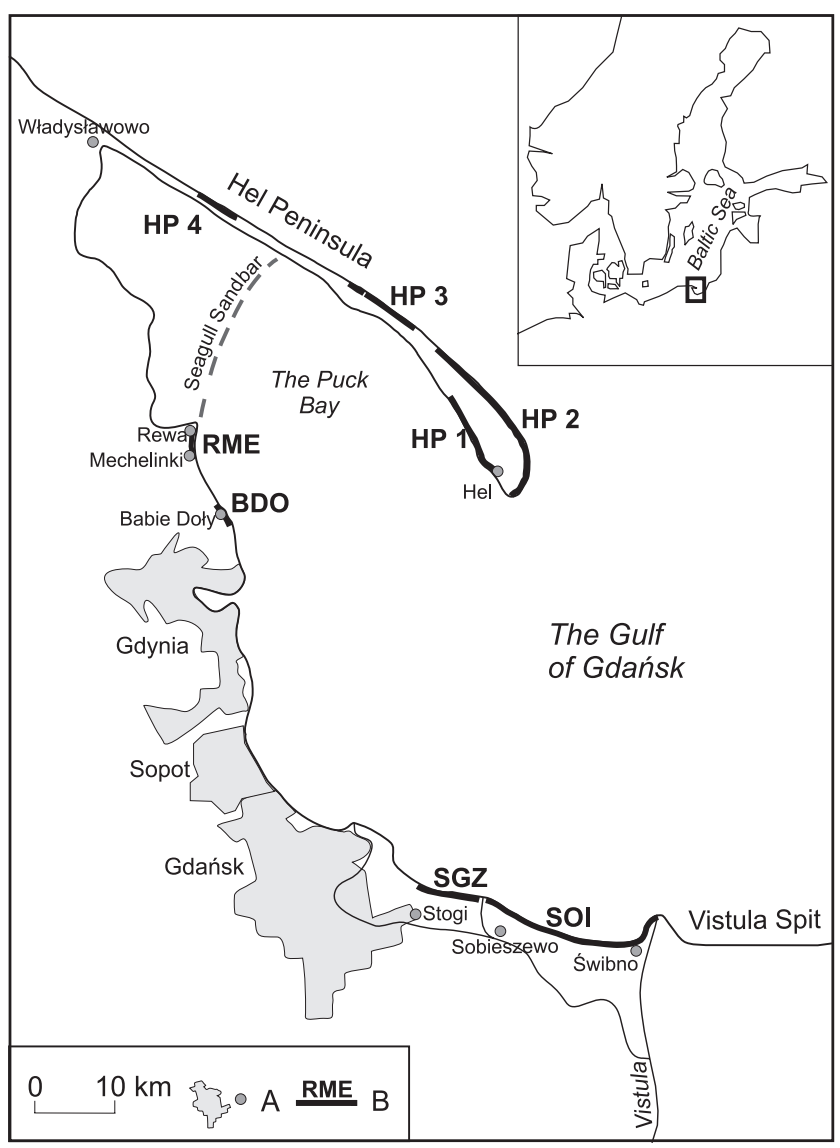

Fig. 1. Location of the studied populations of Eryngium maritimum along the Gulf of Gdańsk

Explanations: A - towns and villages; $\mathrm{B}-$ the studied populations, $\mathrm{HP}-\mathrm{Hel}$ Peninsula, RME - Rewa-Mechelinki, BDO - Babie Doły, SGZ - StogiGórki Zachodnie, SOI - Sobieszewo Island 
Table 1. Number of Eryngium maritimum individuals studied for allozyme diversity collected in particular localities in the Gulf of Gdańsk and their geographic location

\begin{tabular}{lrrrrr}
\hline Locality & Code & $\begin{array}{c}\text { Latitude } \\
(\mathrm{N})\end{array}$ & $\begin{array}{c}\text { Longitude } \\
(\mathrm{E})\end{array}$ & $\begin{array}{c}\text { Total } \\
\text { number of } \\
\text { individuals }\end{array}$ & $\begin{array}{c}\text { Number } \\
\text { of sampled } \\
\text { individuals }\end{array}$ \\
\hline Rewa-Mechelinki & RME & $54^{\circ} 37^{`} 12^{\prime \prime}$ & $18^{\circ} 30^{`} 34^{\prime \prime}$ & 3381 & 47 \\
Hel Peninsula, south side - stretch 1 & HP1 & $54^{\circ} 36^{`} 36^{\prime \prime}$ & $18^{\circ} 47^{`} 45^{\prime \prime}$ & 228 & 28 \\
Hel Peninsula, north side - stretch 2 & HP2 & $54^{\circ} 38^{`} 11^{\prime \prime}$ & $18^{\circ} 41^{`} 32^{\prime \prime}$ & 770 & 68 \\
Hel Peninsula, north side - stretch 3 & HP3 & $54^{\circ} 41^{`} 49^{\prime \prime}$ & $18^{\circ} 41^{`} 32^{\prime \prime}$ & 37 & 19 \\
Hel Peninsula, north side - stretch 4 & HP4 & $54^{\circ} 45^{`} 15^{\prime \prime}$ & $18^{\circ} 21^{`} 48^{\prime \prime}$ & 23 & 10 \\
Babie Doły & BDO & $54^{\circ} 34^{`} 59^{\prime \prime}$ & $18^{\circ} 32^{`} 30^{\prime \prime}$ & 35 & 8 \\
Stogi-Górki Zachodnie & SGZ & $54^{\circ} 22^{`} 20^{\prime \prime}$ & $18^{\circ} 45^{\prime} 20^{\prime \prime}$ & 283 & 34 \\
Sobieszewska Island & SOI & $54^{\circ} 21^{`} 03^{\prime \prime}$ & $18^{\circ} 51^{`} 14^{\prime \prime}$ & 1408 & 50 \\
\hline
\end{tabular}

hydrogenase (G3PDH, EC. 1.2.1.12), phosphoglucomutase (PGM, EC. 5.4.2.2), alcohol dehydrogenase (ADH, EC. 1.1.1.1), isocitrate dehydrogenase (IDH, EC. 1.1.1.42), malic enzyme (ME, EC. 1.1.1.40) and hexokinase (HK, EC. 2.7.1.1) showed a high resolution with L-histidine $\mathrm{HCl} /$ citrate buffer (pH 7.0/7.0) (Cheliak \& Pitel 1984). Diaphorase (DIA, EC. 1.6.2.2), aspartate aminostansferase (AAT, EC. 2.6.1.1), superoxide dismutase (SOD, EC 1.15.1.1) and esterase (EST, EC. 3.1.1.-) gave better results with a lithium-borate/Triscitrate buffer system (pH 8.3/8.1) (Soltis et al. 1983). Uridine 5-diphosphoglucose pyrophosphorylase (UDP, EC. 2.7.7.9), malate dehydrogenase (MDH, EC. 1.1.1.37), 6-phosphogluconate dehydrogenase (6PGD, EC. 1.1.1.44), glucose 6-phosphate isomerase (GPI, EC. 5.3.1.9) were resolved on a morpholine-citrate system (pH 6.5) following Wendel \& Weeden (1989).

Our staining methodology followed Wendel \& Weeden (1989), Soltis et al. (1983) and Manchenko (1994) for UDP. Some polymorphic and monomorphic samples were run at least twice to confirm identified electromorphs. Genetic bases of the banding patterns for the enzymes were inferred from the minimal expected conserved number of isozymes for diploid plants (Gottlieb 1981; Weeden \& Wendel 1989).

\subsection{Data analysis}

Standard measures of genetic diversity for each population and across all populations were calculated using TFPGA software (Miller 1997): percentage of polymorphic loci $(P)$, number of alleles per locus $(A)$ and number of alleles per polymorphic locus (Ap), average observed ( $\mathrm{Ho})$ and expected $(\mathrm{He})$ heterozygosity. The gene diversity within each population was correlated with the total log population size. The correlation between the log number of sampled plants and gene diversity was tested by Spearman's rank coefficient test implemented in STATISTICA v.9 (StatSoft Inc. 2009) to determine any sampling bias. Deviations from HardyWeinberg equilibrium (HWE) at each polymorphic locus and between loci were tested using the exact test with the Markov Chain algorithm (1000 random per- mutations) with Genepop v.4.0.10 software (Raymond \& Rousset 1995; Rousset 2008).

The exact test of population differentiation was carried out to examine the hypothesis of homogeneity of allele frequencies within each population (10 000 random permutations) using Arlequin 3.0 (Excoffier $e t$ al. 2005). To quantify population differentiation, an analysis of molecular variance (AMOVA; Excoffier et al. 1992), based on allele frequencies, as well as the pairwise $\mathrm{F}_{\mathrm{ST}}$, were calculated using Arlequin 3.0 (Excoffier et al. 2005). Significance levels were obtained after performing 10000 random permutations. The tests of differences in genetic diversity measures (allelic richness, Hs, Ho) between groups of population were conducted with FSTAT ver. 2.9.3 (Goudet 2001). The two-sided $p$-values were obtained after 10000 permutations.

The UPGMA cluster analysis of pairwise Nei's (Nei 1978 ) unbiased genetic distances $(D)$, was calculated by TFPGA software (Miller 1997) to test for spatial separation. Gene flow (Nm, the number of migrants per generation) was assessed by Wright's method (Wright 1951). To assess dispersal patterns, pairwise $F_{S T} /(1-$ $\mathrm{F}_{\mathrm{ST}}$ ) were regressed against ln geographic distance among populations measured along the coast and directly, across sea and land. Positive regression between $\mathrm{F}_{\mathrm{ST}}$ and geographic distance indicate an isolation-bydistance effect (Rousset 1997) and we tested for this using the permutation procedure in the Genepop v.4.0.10 software (Raymond \& Rousset 1995; Rousset 2008).

\section{Results}

\subsection{Population resources}

We found 6165 individuals of Eryngium maritimum in the area we studied (Żółkoś et al. 2007). The largest of the populations selected for genetic research $(N=3381)$ was located between the villages of Rewa and Mechelinki. It contained more than a half of all the individuals of the species we found during our field work (Table 1). The second-largest population was 
found on Sobieszewo Island ( $N=1408)$. On the Hel Peninsula, we located 1058 individual Sea Hollies in patches of various sizes and abundance around the peninsula, on the seaboard and on the gulf (Fig. 1). The largest of the four populations we chose on the peninsula was HP2 $(N=770)$ and the smallest was HP4 $(N=23)$. In the Stogi to Górki Zachodnie stretch, we found 283 individuals. The smallest discrete population was found at Babie Doły $(N=35)$ (Table 1$)$.

\subsection{Loci and alleles scored}

We screened 14 of 15 enzyme systems, with 31 loci (Mdh-1, Mdh-2, Mdh3, Mdh-4, Dia-1, Dia-2, Dia-3, Pgd-1, Pgd-2, Skd-1, Skd-2 Est-1, Est-2, Est-1 (fluorescent), G3pdh-1, Gpi-1, Gpi-2, Pgm-2, Pgm3, Adh1, Adh-2, Aat-1, Aat - 2, Idh-1, Idh-2, Sod-1, Sod-2, Udp-1, Udp-2, Hk-1, Hk-2) and 34 alleles were included in the final data analysis. The enzyme ME systems were omitted because they did not show consistently interpretable banding patterns. The Pgm-1 locus was excluded from the analysis because of missing data. Two of the 31 loci were polymorphic (Mdh-2, Udp-1), with a total of four alleles. No symptoms of loci duplication or fixed heterozygosity were found. The remaining 29 loci were monomorphic.

\subsection{Intrapopulation genetic variation}

The percentage of polymorphic loci $(P=6.25)$, the mean number of alleles per locus and the mean allelic richness $(A=1.06, \mathrm{Ap}=2.0)$ were low and of the same value across the populations we studied. The average observed heterozygosity was low $(\mathrm{Ho}=0.022)$ and did not differ significantly from the expected $(\mathrm{He}=0.026)$ under $\mathrm{H}-\mathrm{W}$ equilibrium. The low value of heterozygos- ity was associated with the large number of monomorphic loci in the calculations. Ho ranged from 0.019 in HP2 to 0.028 in BDO and SGZ; He ranged from 0.021 in HP3 to 0.033 in BDO (0.032 in SGZ), (Table 2).

We found no significant correlation between gene diversity and population size or sample size $(p>0.1)$. There were no significant deviations from the HardyWeinberg equilibrium except for locus Udp-1 $(p<0.05)$ in the HP1 and SGZ populations and for locus Mdh-2 in the SOI population, where all were connected with an excess of homozygotes. General conformity with the Hardy-Weinberg expectations contradicted the high average $\mathrm{F}_{\mathrm{IS}}(0.134)$ and $\mathrm{F}_{\mathrm{IT}}(0,160)$ estimate.

\subsection{Population genetic structure}

The total genetic diversity $\left(\mathrm{H}_{\mathrm{T}}\right)$ for all populations was 0.026 . We found a small mean genetic divergence between populations $\left(\mathrm{F}_{\mathrm{ST}}=0.03\right)$ as well as a small genetic distance, not exciding $D=0.003$ (Table 3). However, the exact tests of population differentiation rejected the null hypothesis of no differentiation among populations $(p<0.01)$ and the pairwise $\mathrm{F}_{\mathrm{ST}}$ showed nine significant differences in the 28 comparisons (see Table 3 ). One of the highest genetic distances $(D=0.0021)$ was observed in adjacent populations (HP1-HP2), which might suggest barriers to gene flow between those populations. For comparison, other neighboring populations (HP2-HP3) revealed one of the lowest distances $(D=0.0001)$. The analysis of molecular variance (AMOVA) partitioned only $3 \%\left(\mathrm{~F}_{\mathrm{ST}}=0.3, p<0.01\right)$ of the total variation among population differences.

A dendrogram based on the Nei (1978) genetic distance $(D)$ and the UPGMA clustering algorithm (Fig. 2 ) grouped populations in two clusters. The first group

Table 2. Genetic variation of studied population of Eryngium maritimum measured as observed (Ho) and expected (He) heterozygosity over all loci

\begin{tabular}{lllllllll}
\hline & RME & HP1 & HP2 & HP3 & HP4 & BDO & SGZ & SOI \\
\hline Ho & 0.026 & 0.021 & 0.019 & 0.023 & 0.023 & 0.028 & 0.028 & 0.023 \\
He & 0.023 & 0.026 & 0.025 & 0.021 & 0.026 & 0.033 & 0.032 & 0.030 \\
\hline
\end{tabular}

Table 3. Nei's (1978) genetic distance (below the diagonal) and values of pairwise $\mathrm{F}_{\mathrm{ST}}$ (above the diagonal) between populations of Eryngium maritimum

\begin{tabular}{lrlllrrrl}
\hline & RME & \multicolumn{1}{c}{ HP1 } & \multicolumn{1}{c}{ HP2 } & \multicolumn{1}{c}{ HP3 } & HP4 & BDO & \multicolumn{1}{c}{ SGZ } & \multicolumn{1}{c}{ SOI } \\
\hline RME & 0.0000 & $0.0367^{*}$ & 0.0070 & -0.0160 & 0.0270 & 0.0600 & $0.0780^{*}$ & $0.0420^{*}$ \\
HP1 & 0.0009 & 0.0000 & $0.0760^{*}$ & $0.0500^{*}$ & 0.0190 & -0.0020 & 0.0380 & $0.0490^{*}$ \\
HP2 & 0.0002 & 0.0021 & 0.0000 & 0.0030 & -0.0240 & 0.0580 & $0.0670^{*}$ & 0.0220 \\
HP3 & -0.0004 & 0.0013 & 0.0001 & 0.0000 & -0.0270 & 0.0800 & $0.0930^{*}$ & $0.0520^{*}$ \\
HP4 & -0.0007 & 0.0005 & -0.0006 & -0.0007 & 0.0000 & 0.0060 & 0.0280 & -0.0030 \\
BDO & 0.0013 & -0.0002 & 0.0013 & 0.0020 & 0.0001 & 0.0000 & -0.0370 & -0.0150 \\
SGZ & 0.0023 & 0.0012 & 0.0019 & 0.0029 & 0.0009 & -0.0012 & 0.0000 & -0.0002 \\
SOI & 0.0013 & 0.0015 & 0.0006 & 0.0016 & 0.0000 & -0.0006 & 0.0000 & 0.0000 \\
\hline
\end{tabular}

Explanation: * - significant value based on 10000 permutations 


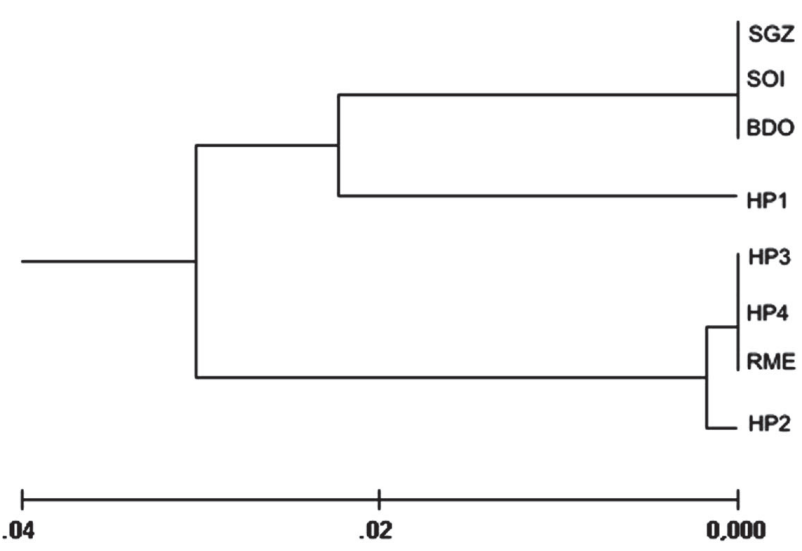

Fig. 2. Dendrogram of the UPGMA cluster analysis based on Nei's (1978) measure of genetic distance (bar). Bar represents value of genetic distance

consisted of populations from the north of our study area, on the Hel Peninsula (HP2, HP3, HP4) and between Rewa and Mechelinki (RME); the second cluster in the south included Babie Doły (BDO), Górki Zachodnie (SGZ) and Sobieszewo Island (SOI) (see Fig. 1). HP1, although situated in the north, differed from both groups in terms of genetic distances.

These two groups of populations (excluding HP1) differed significantly in average expected heterozygosity (0.022 and $0.025, p<0.01$, for northern and southern respectively) as well as allelic richness (1.063 and 1.065 $p<0.05)$. The exact test also showed significant differences $(p<0.001)$ among groups in allele frequency. Allele frequency in population HP1 differed significantly from both of these groups as shown by the exact test $(p<0.01)$. Regression of pairwise $\mathrm{F}_{\mathrm{ST}}$ values against geographic distance was low and was not significantly different from zero (Mantel test) with $b=-0.004(p>0.39)$ for the coastline and $b=0.003(p>0.2)$ for the direct measure. Excluding the most differentiated population (HP1) improved correlations, but the results were still statistically insignificant. The number of migrants per generation exceeded three individuals $(\mathrm{Nm}=3.56)$.

\section{Discussion}

\subsection{Genetic variation}

The populations of Eryngium maritimum we studied showed low levels of genetic diversity. The calculated parameters $\left(P=6.25, A=1.06, \mathrm{Ht}=0.026, \mathrm{~F}_{\mathrm{ST}}=0.03\right)$ were considerably lower than those found in other plant species with similar biology: allogamic $(P=51.07, A=1.85$, $\left.\mathrm{Ht}=0.251, \mathrm{G}_{\mathrm{ST}}=0,118\right)$ and entomogamic $(P=38.83$, $A=1.55, \mathrm{Ht}=0.393, \mathrm{G}_{\mathrm{ST}}=0.224$ ) (Hamrick et al. 1979; Loveless \& Hamrick 1984). Studies by Curle et al. (2007) showed a low level of allozyme diversity in

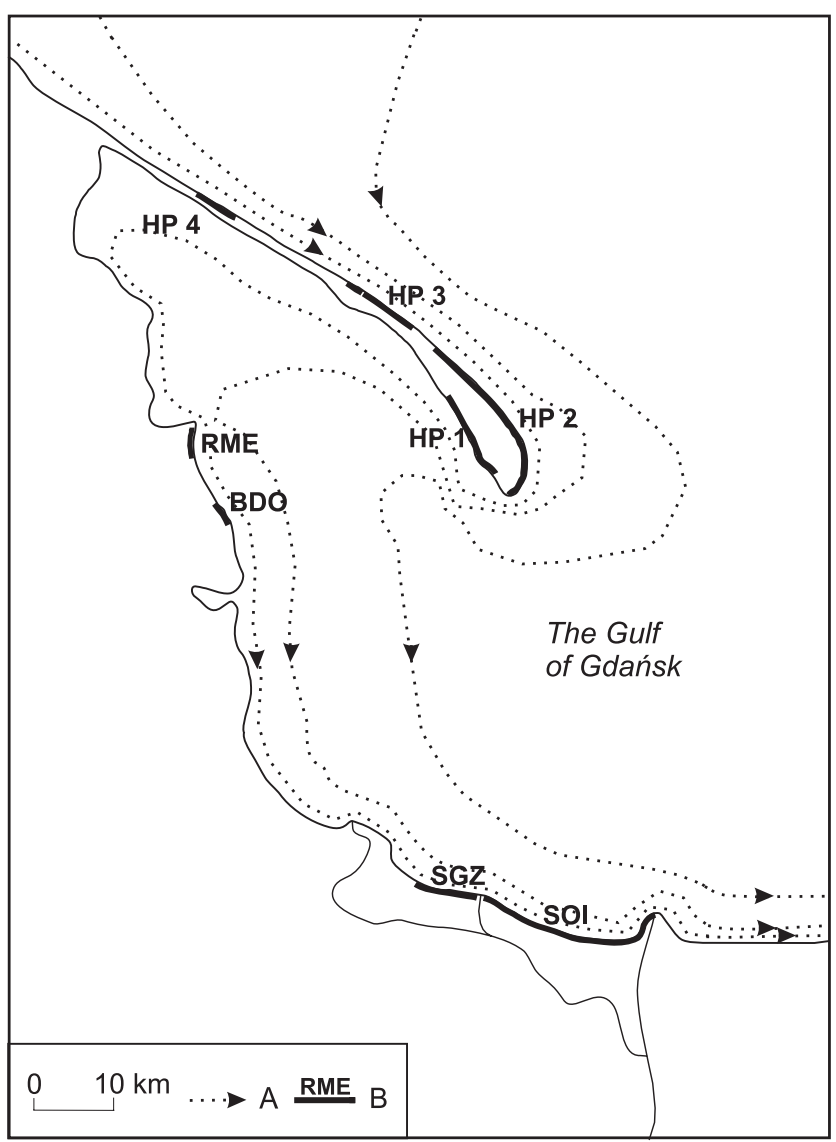

Fig. 3. The main pattern of dominant sea currents in the Gulf of Gdańsk in autumn and winter

Explanations: A - direction of currents influenced by the western wind, B location of the studied populations of Eryngium maritimum (Abbr. as in Fig. 1)

Norwegian populations of this species. Studies applying more variable markers (AFLP) than allozymes also showed low variability of Sea Holly in other parts of the species range (Westberg \& Kadereit 2008). The low level of diversity is probably associated with a bottleneck during the postglacial migration from the Mediterranean refugium (see Hewitt 1999; Clausing et al. 2000).

\subsection{Population genetic structure}

Sea Holly populations in the area we studied showed a weak genetic structure, which was indicated by the low mean $\mathrm{F}_{\mathrm{ST}}(0.03)$ as well as the low value of the intrapopulation component of AMOVA (3\%). Westberg $\&$ Kadereit (2008) also noted low and statistically nonsignificant value of the last parameter $(4.2 \%$, based on AFLP) for the Sea Holly population in Western France, where no apparent barriers to gene flow occurred. Clausing et al. (2000) and Westberg \& Kadereit (2008) reported a significant effect that the direction of sea currents played on the geographic pattern of Sea Holly genetic variation. The shoreline configuration, bottom 
topography and water exchange with the Baltic Proper Sea favor characteristic hydrological conditions (Kowalik 1975) that might trace the main routes of the diaspore transport. The main pattern of sea currents circulation (Fig. 3), (see Kowalik 1990) is strongly influenced by the wind direction and is therefore variable, especially on the sea surface (Jędrasik et al. 2008). Western winds dominate in autumn and winter, when Sea Holly seed dispersal rate probably peaks. These winds drive the water eastwards, which causes water to flow into the Gdańsk Basin from the northern part of the Hel Peninsula (Kowalik 1990; Jędrasik et al. 2008) towards the north-west, west and south-east. In the same period, the eastern and southern winds occur occasionally. The eastern winds blowing parallel to the Vistula Spit cause a flow of water along the sea shore of the studied area, while the southern winds cause currents to flow mainly north-eastwards. Mean current flows caused by winds, despite of their direction, are often disturbed close to the outer end of the Hel Peninsula (Kowalik 1975).

E. maritimum seed migration in either direction is probably not restricted in the western part of Gdańsk Bay based on the main pattern of sea currents circulation and the dominant wind directions. However, gene flow between RME and the nearby BDO is unlikely because the prevailing western winds and the sea current parallel to the coast should hamper seed immigration by water. Transport by land would be blocked by the cliffs along the shore RME and BDO with no beaches between them. The cliffs and strong winds would also prevent insect-mediated pollen flow.

Despite the small genetic differences between the populations, their clear grouping in the UPGMA analysis, mostly congruent with their geographic locations, indicated that barriers to gene flow did exist. The lack of a significant correlation between genetic and geographical distances in the populations as shown by the Mantel test also indicated an imbalance between drift and migration. However, the distance between the populations was too small to capture such a relationship, which could also explain this phenomenon. Westberg $\&$ Kadereit (2008) also seldom found a positive correlation over the relatively short distances of the coasts they surveyed. Other researchers observed strong positive correlations over long distances (Clausing et al. 2000; Kadereit et al. 2005). The significant differences in allele frequency among nearby populations indicated that drift dominated over migration in shaping their genetic structure. This might occur when gene flow and/ or seedling recruitment is low. As inferred from the directions of the main water currents and the dominant wind directions, gene flow by seed did not seem to be restricted in the area we studied, except for BDO and RME. However, the efficiency of migration might be limited by Sea Holly relatively low seed fertility, low and rapidly declining viability of seeds (Walmsley \& Davy 1997), their low floating ability of two to six days (Curle et al. 2007; Westberg \& Kadereit 2008) and the low seedling establishment we observed (Stasiak 1988; Żółkoś, Markowski, unpubl.). The low efficacy of gene flow by seed could also explain the divergence of the northern and southern population groups.

RME and the populations on the Hel Peninsula were probably connected by gene flow in the past. This was facilitated by the presence of large sand dunes, which could be associated with the significantly smaller forest cover on the peninsula, and the land bridge between Rewa and the peninsula that had existed before sea levels were raised and the inner part of Puck Bay was formed. This may explain genetic similarities of these populations. The genetic divergence of the HP1 population we found might be a result of isolation. Among the possible causes are: increasing afforestation of the eastern Hel Peninsula in the second half of the nineteenth century (Tomczak 2005), leading to the separation of the beaches on the seaboard and the gulf as well as the construction of breakwaters for the fishing port more than 120 years ago and a naval base more than 80 years ago near the town of Hel. Local Sea Holly plants might have died out during the construction and others might have been introduced accidentally in forms of rhizomes and seeds in soil taken from remote places. Substrate enrichment related to the construction works might also have enabled a higher rate of seed germination and seedling establishment. On the other hand, the exclusion of the public from beaches by the military probably secured the population from the destructive influence of tourism. Gene flow from the neighboring seaside populations at Hel (HP2 and HP3) might have been limited in the past, as it is today, by the difficulties in transport faced by propagules, by land because of afforestation and by sea. The two breakwaters probably limit migrant seed access to the shore, thus maintaining isolation.

The genetic distinctiveness of the populations might also be explained by local extinctions and the re-establishment of populations in a relatively short period, so little time was available for them to reach equilibrium. However, long-term observations of Sea Holly populations in the area we studied did not support this theory because the plants reproduced mainly vegetatively (Żółkoś, Markowski, unpubl.). Juvenile plants of generative origin are seldom observed and then only in extraordinary circumstances on enriched substrates, such as organic debris washed ashore.

\subsection{Consequences of habitat fragmentation}

The development of the Tri-city agglomeration (Gdańsk, Sopot and Gdynia), industrial infrastructure 
and tourism fragmented the habitat over at least the past 120 years and significantly reduced the size of Sea Holly populations in the area we studied (Kulesza 1928; Lubliner-Mianowska 1958; Ćwikliński 1978; Żółkoś et al. 2007). Habitat fragmentation can limit genetic diversity and demographic processes in plant populations (Young et al. 1996; Aguilar et al. 2006). The populations of the Sea Holly we studied, with their low genetic diversity and gradual loss of abundance, might have been particularly vulnerable to the effects of habitat fragmentation. However, we observed no significant correlations between the size of the populations and their gene diversity. The BDO population was the smallest we studied but the most diverse, although there was no reliable information of its occurrence and size in the past because this stretch of coast had long been a military area with restricted access. The relationship between the population size and genetic structure is rarely straightforward (van Treuren et al. 1993). Among the reasons for this, could be possible mismatches between effective population and census population sizes. These could be especially pronounced in clonally propagating plants like E. maritimum. The lack of significance might suggest that the populations we sampled were large enough to maintain genetic diversity. However, the most likely explanation is that there might have been too few generations since the habitat became fragmented to allow the loss of diversity. Clonally propagating and long-living species can persist long after habitat fragmentation (Eriksson \& Ehrle'n 2001). The clonal growth of the Sea Holly causes a time laps between generations, which might buffer the genetic effect of fragmentation because a drift strongly depends on the number of generations over which a population remains small (Barrett \& Kohn 1991). On the other hand, clonal propagation might hasten genetic drift by reducing the effective population size (Chung \& Kang 1996; Jones \& Gliddon 1999). However, in long-lived plants even low seedling establishment can maintain genetic diversity (Watkinson \& Powell 1993; Stehlik $\&$ Holderegger 2000). The effects of a genetic drift was found to be similarly mitigated in the long-lived clonal species Calystegia collina (Wolf et al. 2000), Cypripedium calceolus (Brzosko et al. 2002) and Maianthemum bifolium (Honnay et al. 2006).

The founder effect and isolation caused by anthropogenic and natural factors might have influenced the genetic structure of Eryngium maritimum populations in the areas we studied. However, estimating what effect contemporary fragmentation of costal habitats has on populations of Sea Holly would require a study on the current gene flow pattern by pollen and seeds as well as on the establishment of seedlings.

\subsection{Conservation implications}

The size of the Eryngium maritimum populations in the part of the Gulf of Gdańsk that we studied (more than 6000 individuals - Żółkoś et al. 2007) does not indicate a need for any radical and expensive approach to conservation, such as introductions or reintroductions. However, augmentation of the existing populations would be desirable, particularly in areas where Eryngium maritimum occurs sporadically: between the town of Władysławowo and the village of Kuźnica along the seaboard of the Hel Peninsula, as well as in the stretch between Stogi and Górki Zachodnie. The similar values in the genetic variability of all the populations we studied would allow to obtain an arbitrary collection of seeds for plant multiplying, for possible augmentation of the species populations. Collecting seeds from the large and diverse population at SOI would seem to be the most appropriate strategy.

Maintaining the continuity of migration is important for the sustainability of the Sea Holly populations, especially because seeds of this species quickly lose viability (70\% per year - Walmsley \& Davy 1997). A fraction of seeds are transported, at least in the early stages of migration, on withered shoots blown along the beach as tumbleweeds and also float on the water. Therefore, it is inadvisable to fence dunes or beaches. Fences might hinder the flow of the propagules, leading to genetic erosion in isolated populations. This is particularly important for the RME and SOI populations, which comprise $52.2 \%$ and $21.7 \%$ respectively of all plants of this species counted in the study area (Żółkoś et al. 2007) and which might constitute an important source of seeds for the entire region.

The most critical threats to the Eryngium maritimum populations in all the locations we studied comprised fragmentation and destruction of suitable habitats resulting from the intense anthropogenic pressure associated with the management of seashores for economic reasons, particularly tourism. Populations of $E$. maritimum in the Gulf of Gdańsk should be monitored. Where economic investment of strategic importance for the region and country is allowed that might result in permanent destruction of these species habitats, threatened populations should be protected by metaplantation into suitable sites. An example of this type of compensation and minimization was a metaplantation of Sea Holly from the site of the Gdańsk Container Terminal to the location on the Sobieszewo Island (Żółkoś et al. 2010).

Acknowledgments. This work was supported by the Regional Fund for Environmental Protection and Water Management in Gdańsk (WFOŚ/D/515/72//2006). 


\section{References}

Aguilar R., Ashworth L., Galetto L. \& Aizen M. A. 2006. Plant reproductive susceptibility to habitat fragmentation: review and synthesis through a meta-analysis. Ecol. Lett. 9: 968-980.

Aviziene D., Pakalnis R. \& Sendzikaite J. 2008. Status of red-listed species Eryngium maritimum L. on the Lithuanian coastal dunes. In: D. CygAs \& K. D. FroEhNER (eds.). Environmental Engineering. The $7^{\text {th }}$ International Conference, pp. 22-28. Gediminas Technical University, Vilnus.

Barrett S. C. H. \& Kohn J. R. 1991. Genetic and evolutionary consequences of small population size in plants: implications for conservation. In: D. A. FALK \& K. E. Holsinger (eds.). Genetics and Conservation of Rare Plants, pp. 3-30. Oxford Univ. Press, New York.

Brzosko E., Wróblewska A. \& Ratkiewicz M. 2002. Spatial genetic structure and clonal diversity of island populations of ladys slipper (Cypripedium calceolus) from the Biebrza National Park (northeast Poland). Mol. Ecol. 11: 2499-2509.

BulaK J. \& Woch W. 2007. Ocena liczebności populacji mikołajka nadmorskiego Eryngium maritimum na wydmach nadmorskich na terenie Parku Krajobrazowego 'Mierzeja Wiślana' i jego otuliny. Gawron 2(43): 4-9.

Cheliak W. M. \& Pitel J. A. 1984. Techniques for starch gel electrophoresis of enzymes from forest trees species. Inf. Rep. Pl-X-42, Petawawa National Institute, Canadian Forestry Service.

Clausing G., Vickers K. \& Kadereit J. W. 2000. Historical biogeography in a linear system: genetic variation of Sea Rocket (Cakile maritima) and Sea Holly (Eryngium maritimum) along European coasts. Mol. Ecol. 9: 1823-1833.

Chrzanowski B. 1920. Na kaszubskim brzegu: zwięzły przewodnik z sześciu krajobrazami i mapą. 113 pp. Książnica Polska Towarzystwa Szkół Wyższych, Lwów-Warszawa.

Chung M. G. \& Kang S. S. 1996. Allozyme genetic and clonal diversity within populations of Chimaphila japonica and Pyrola japonica (Pyrolaceae). Isr. J. Plant Sci. 44: 259-271.

Curle C. M., Stabbetorp O. \& Nordal I. 2007. Eryngium maritimum, biology of a plant at its northernmost localities. Nordic J. Bot. 24(5): 617-628.

ĆWIKLIŃSKI E. 1972. Rozmieszczenie mikołajka nadmorskiego Eryngium maritimum na wybrzeżu szczecińskim. Chrońmy Przyr. Ojcz. 28(4): 21-29.

ĆWikLiński E. 1978. Problem ochrony mikołajka nadmorskiego Eryngium maritimum na polskim wybrzeżu. Chrońmy Przyr. Ojcz. 34(6): 5-14.

ERIKSSON O. \& EHRLE'N J. 2001. Landscape fragmentation and the viability of plant populations. In: J. SILVER-
TOWN \& J. ANTONOVICS (eds.). Integrating ecology and evolution in a spatial context, pp. 157-175. Blackwell Science, Oxford.

Excoffier L., Smouse P. \& Quattro J. 1992. Analysis of molecular variance inferred from metric distances among DNA haplotypes: Application to human mitochondrial DNA restriction data. Genetics 131: 479491.

Excoffier L., LAval G. \& SchneIder S. 2005. Arlequin (version 3.0) an integrated software package for populations genetic data analysis. Evolutionary Bioinformatics Online 1: 47-50.

Felsenstein J. 2005. PHYLIP (Phylogeny Inference Package) version 3.6. Distributed by the author. Department of Genome Sciences, University of Washington, Seattle.

Fischer M., van Kleunen M. \& Schmid B. 2000. Genetic allee effects on performance, plasticity and developmental stability in a clonal plant. Ecol. Lett. 3: 530539.

FrankHAm R. 2005. Genetics and extinction. Biol. Cons. 126: 131-140.

Gertsmannowa E. 1995. Półwysep Helski - przyrodnicze podstawy rozwoju. 79 pp. IOŚ Warszawa.

Gerstmannowa E. \& Lenartowicz Z. 1995. Walory, zagrożenia i zasady ochrony przyrody w strefie nadmorskiej. In: M. PRZEWOźnIAK (ed.). Ochrona Przyrody w regionie gdańskim, pp. 139-148. Bogucki Wyd. Nauk., Poznań.

Gottlieb L. D. 1981. Electrophoretic evidence and plant populations. Prog. Phytochem. 7: 1-46.

GOUDET J. 2001. FSTAT, a program to estimate ant test gene diversities and fixation indices (ver. 2.9.3). Updated from Goudet J. 1995. Fstat (ver. 1.2) a computer program to calculate F-statistics. J. Hered. 86: 485486.

HAMrick J. L., Linhart Y. B. \& MitTon J. B. 1979. Relationships between life history characteristics and electrophoretically detectable genetic variation in plants. Ann. Rev. Eol. Syst. 10: 173-200.

Herweg O. 1914. Flora der Kreise Neustadt und Putzig in Westpreuâen. Ber. Versamml. Westpreuss. Bot.-Zool. Vereins Danzig 37: 85-331.

Hewitt G. M. 1999. Post-glacial re-colonization of European biota. Biol. J. Linn. Soc. 68: 87-112.

Honnay O., Jacquemyn H., Rolda'n-Ruiz I. \& Hermy M. 2006. Consequences of prolonged clonal growth on local and regional genetic structure and fruiting success of the forest perennial Maianthemum bifolium. Oikos 112(1): 21-30.

Hultén E. \& Fries M. 1986. Atlas of North European vascular plants. North of the Tropic of Cancer. IIII. xvi+1172 pp. Koeltz Scientific Books, Königstein. 
Jędrasik J., Cieślikiewicz W., Kowalewski M., BradtKe K. \& JANKOwsKi A. 2008. 44 Years Hindcast of the sea level and circulation in the Baltic Sea. Coastal Engineering 55: 849-860.

Jones B. \& GLiddon C. 1999. Reproductive biology and genetic structure of Lloydia serotina. Plant Ecol. 141: 151-161.

Kadereit J. W., Arafeh R., Somogyi G. \& Westberg E. 2005. Terrestrial growth and marine dispersal? Comparative phylogeography of five coastal plant. Taxon 54(4): 861-876.

Kowalik Z. 1975. Metody prognozowania zmian poziomu morza oraz prądów wywołanych wiatrem. Oceanologia 4: 5-111.

Kowalik Z. 1990. Hydrologia i hydrochemia. In: A. MAJEwsKI (ed.). Zatoka Gdańska, pp. 120-328. Wyd. Oceanologiczne, Warszawa.

KowALSKI A. (ed.) 2001. Locja Bałtyku. Wybrzeże polskie nr 502. 7 ed.: 206. Biuro hydrograficzne Marynarki Wojennej, Gdynia.

Kulesza W. 1924. Strefy roślinności nadmorskiej na wybrzeżach w okolicy Rewy. Kosmos 49(3): 787-816.

Kulesza W. 1928. W sprawie ochrony mikołajków nadmorskich na polskim wybrzeżu. Ochrona Przyr. 7: 141 .

Loveless D. M. \& HAMrick J. L. 1984. Ecological determinants of genetic structure in plant populations. Ann. Rev. Ecol. Syst. 15: 65-95.

Lubliner-Mianowska K. 1958. Rozmieszczenie mikołajka nadmorskiego na wybrzeżu gdańskim, stan z roku 1957. Chrońmy Przyr. Ojcz. 14(5): 42-47.

Manchenko G. P. 1994. Handbook of Detection Enzymes on Electrophoretic Gels. 228 pp. C.R.C. Press, Ann Arbor.

Markowski R. \& Buliński M. 2004. Ginące i zagrożone rośliny naczyniowe Pomorza Gdańskiego. Acta Bot. Cassub. Monogr. 1: 1-75.

Miller M. 1997. Tools for population genetic analysis (TFPGA). A windows program for the analysis of allozyme and molecular population genetic data, version 1.3 , Computer software distributed by the author.

NEI M. 1978. Estimation of average heterozygosity and genetic distance from a small number of individuals. Genetics 89: 583-590.

Piotrowska H. 2002. Zbiorowiska psammofilne na wydmach polskiego brzegu Bałtyku. Acta Bot. Cassub. 3: 5-47.

Preuss H. 1911. Die Vegetationsverhältnisse der westpreussischen Ostseeküste. Ber. Versamml. Westpreuss. Bot.-Zool. Vereins Danzig 33: 1-119.

RAYMOND M. \& Rousset F. 1995. GENEPOP (version 1.2): population genetics software for exact tests and ecumenicism. J. Heredity 86: 248-249.

REgulation of the Minister of EnViRONMENT OF 09 July 2004 on wild species of plants under protection. Journal of Laws No 168 (2004), item 1764.

Rousset F. 1997. Genetic differentiation and estimation of gene flow from F-statistics under isolation by distance. Genetics 145: 1219-1228.
RouSSET F. 2008. Genepop'007: a complete reimplementation of the Genepop software for Windows and Linux. Mol. Ecol. Resources 8: 103-106.

Soltis D. E., Haufler C. H., Darrow D. C. \& Gastony G. J. 1983. Starch gel electrophoresis of ferns: a compilation of grinding buffers, gel and electrode buffers and staining schedules. Amer. Fern J. 73: 9-27.

StASIAK J. 1988. Eryngium maritimum L. In: A. JASIEWICZ (ed.). Materiały do poznania gatunków rzadkich i zagrożonych Polski, cz. 1. Fragm. Flor. Geobot. 33(34): 355-368.

StATSoft Inc. 2009. STATISTICA (data analysis software system), ver. 9. www.ststsoft.com

Stehlik I. \& Holderegger R. 2000. Spatial genetic structure and clonal diversity of Anemone nemorosa in late successional deciduous woodlands of central Europe. J. Ecol. 23: 424-435.

TomczaK A. 2005. Wybrane zagadnienia z przeszłości geologicznej i przyszłości Półwyspu Helskiego. In: J. Cyberski (ed.). Stan i zagrożenie Półwyspu Helskiego, pp. 13-58. Gdańskie Towarzystwo Naukowe, Gdańsk.

van Treuren R., Bijlsma R., Ouborg N. J. \& van Delden W. 1993. The effect of population size and plant density on outcrossing rates in Salvia pratensis. Evolution 47: 1094-1104.

URBAŃSKi J. 1933. Mapa zabytków przyrody polskiego wybrzeża. Wyd. Okręg. Kom. Ochr. Przyr. na Wielkopolskę i Pomorze 4: 5-20.

Walmsley C. A. \& Davy A. J. 1997. Germination characteristics of shingle beach species, effects of seed ageing and their implications for vegetation restoration. J. Appl. Ecol. 34: 13-42.

Watkinson A. R. \& Powell J. L. 1993. Seedling recruitment and the maintenance of clonal diversity in plant populations. J. Ecol. 81: 707-717.

Weeden N. F. \& Wendel J. F. 1989. Genetics of plant isozymes. In: D. E. Soltis \& P. S. Soltis (eds.). Isozymes in plant biology, pp. 46-72. Dioscorides Press, Portland.

Wendel J. F. \& WeEden N. F. 1989. Visualization and interpretation of plant isozymes. In: D. E. Soltis \& P. S. Soltis (eds.). Isozymes in plant biology, pp.5-45. Dioscorides Press, Portland.

Westberg E. \& Kadereit J. W. 2008. The influence of sea currents, past disruption of gene flow and species biology on the phylogeographical structure of coastal flowering plants. J. Biogeogr. 36(7): 13981410.

Wolf A. T., Howe R. W. \& Hamrick J. L. 2000. Genetic diversity and population structure of the serpentine endemic Calystegia collina (Convolvulaceae) in northern California. Am. J. Bot. 87: 1138-1146.

Wright S. 1951. The genetical structure of populations. Ann. Eugen. 15: 323-534.

Young A., Boyle T. \& Brown A. 1996. The population genetic consequences of habitat fragmentation for plants. TREE 11: 413-418.

ŻóŁkoś K., Afranowicz R., Bloch-OrŁowska J. \& Kozię K. 2007. Distribution and resources of Sea Holly 
(Eryngium maritimum L.) on the western shore of Gulf of Gdańsk. Biodiv. Res. Conserv. 5(8): 55-60.

Żółkoś K., Afranowicz R., Boch-OrŁowska J. \& MinasiewiCZ J. 2010. Problems of metaplantation of protected species - a case study of Sea Holly (Eryngium maritimum L.) and Dark Red Helleborine (Epipactis atrorubens (Hoffm.) Besser). Balt. Coast. Zone. 14: 17-24. 